Check for updates

The BMJ

Cite this as: $B M J$ 2021;373:n965 http://dx.doi.org/10.1136/bmj.n965 Published: 13 April 2021

\title{
Covid-19: Government faces legal action over contract for antibody tests
}

\section{Clare Dyer}

The non-profit organisation the Good Law Project has been given the go ahead to mount a High Court challenge to the UK government's decision to award contracts to Abingdon Health to produce rapid antibody tests for covid-19.

The Department of Health and Social Care for England bought a million lateral flow test kits from the UK Rapid Testing Consortium, a group of manufacturers led by Abingdon Health and assembled by John Bell, regius professor of medicine at Oxford University and the government's life sciences adviser. ${ }^{1}$

The contract, which was awarded without competitive tender, included a provision for the government to buy more kits if the test was approved for home use by the Medicines and Healthcare Products Regulatory Agency by a specified date. But the approval was not forthcoming, and England's health secretary, Matt Hancock, announced in January that the government was moving to a different procurement strategy.

A study by Public Health England, published in November in The BMJ, ${ }^{2}$ estimated that the accuracy of the $\mathrm{AbC}-19$ rapid tests in real world conditions was less than had been thought. Assuming that $10 \%$ of the tested population had been infected with SARS-CoV-2, around one in five key workers testing positive would be false positives, the study said.

Mrs Justice O'Farrell ruled on 3 March, after arguments presented on paper, that the Good Law Project could challenge the government's decisions in awarding the contracts but on one ground only: that the award breached the government's equal treatment obligations. Now Mr Justice Waksman, after hearing both sides, has considerably widened the scope of the challenge.

His decision means that the Good Law Project has the go ahead to argue, when the case reaches court, that:

- there was apparent bias in the award of the contracts, given that Bell was on "both sides of the contract" as government legal adviser and a major figure in the UK Rapid Testing Consortium

- the government awarded the contracts to Abingdon Health unlawfully by giving it preferential treatment because it was a British company

- the decision to award the contracts breached the government's obligations of equal treatment, transparency, and proportionality

- the contract awards led to unlawful state aid, and

- the government acted irrationally when awarding the contracts to Abingdon Health.
The government has estimated that it will cost around $£ 670$ ooo to defend the case. The Good Law Project has so far raised more than $£ 85000$ through crowdfunding and is asking for a cost capping order to limit its liability should it lose.

Jolyon Maugham QC, the project's director, said, “The court's decision means the government will no longer be able to fob us off. In particular, it will be forced to disclose details of the decision making process as part of these proceedings."

The health department said in a statement, "Meeting the urgent challenges created by this global pandemic required the combined efforts and expertise of the public and private sector. We have been clear from the outset that public authorities must achieve value for taxpayers and apply good commercial judgment."

In a statement a spokesman for Abingdon Health said it was "aware of the challenge to DHSC and its procurement processes. Many of the facts relating to Abingdon Health that have been reported in this matter are inaccurate or wrong. We expect correct and accurate information will be put before the court before any final determination is made."

The BMJ asked Oxford University for a comment on behalf of Bell but at the time of going to press had received no response.
1 Armstrong S. Covid-19: Government pursued in the courts over controversial antibody test. BM/2021:372:n626. doi: 10.1136/bmj.n626 pmid: 33664019
2 Mulchandani R, Jones HE, Taylor-Phillips S, etalEDSAB-HOME and COMPARE Investigators. Accuracy of UK Rapid Test Consortium (UK-RTC) "AbC-19 Rapid Test" for detection of previous SARS-CoV-2 infection in key workers: test accuracy study. BMJ2020;371:m4262.pmid: 33177070

This article is made freely available for use in accordance with BMJ's website terms and conditions for the duration of the covid-19 pandemic or until otherwise determined by BMJ. You may use, download and print the article for any lawful, non-commercial purpose (including text and data mining) provided that all copyright notices and trade marks are retained. 